\title{
Comparative Analysis of Heating, Ventilation and Electricity Costs on the Example of Residential Building in the Near Zero-Energy Standard
}

Abstract: This article deals with an analysis of the operating costs of a building designed in the "near zero-energy" standard, with various technological solutions for heating and ventilation supported by a photovoltaic system (three technological variants). Following the analysis, a technological variant using an economic criterion based on the minimization of annual operating costs was selected.

Keywords: low-energy-consumption building, operating cost, natural gas, heat pump, photovoltaic system

\footnotetext{
* UTP University of Science and Technology, Department of Geomatics and Spatial Economy, Bydgoszcz, Poland
} 


\section{Introduction}

The year 2017 brought changes to Poland regarding its requirements for energy efficiency in residential buildings [1, 2]. Under the new law, the heat transfer coefficient was reduced, which is related, inter alia, to the adoption of the National Energy Efficiency Action Plan for Poland 2017 on January 23, 2018, by the Council of Ministers [3]. The above document contains a description of measures related to the improvement of energy efficiency obtained during the period of 2008-2015 [4] and plans for further savings to be implemented by 2020. The National Energy Efficiency Action Plan is developed every three years due to the obligation to submit reports to the European Commission under the 2006/32/EC [5] and 2012/27/EU directives [4]. In the field of energy efficiency improvement, the European Union has adopted the goal of achieving $20 \%$ savings in primary energy consumption by 2020 . The goal adopted for Poland in 2016 concerning final energy savings in an amount not less than $9 \%$ of the average national energy consumption from 2001-2005 was implemented. In addition, a constant drop in energy intensity has been observed in Poland. Such a tendency is the result of actions aimed at improving energy efficiency and the effect of dynamic GDP growth against the rate of energy consumption. Further activities related to energy management in Poland are to be based on the continuous implementation of a policy aimed at increasing the energy efficiency of the economy and achieving objectives in accordance with the principle of minimizing costs [4, 6]. The National Energy Efficiency Action Plan for a residential building provides for reducing the energy consumption needed to heat a house, preparing domestic hot water, and ventilation. The above plan enables the use of technological solutions that maximize the efficiency of devices, including the use of condensing boilers or heat pumps with a high efficiency ratio [3]. In this context, it is above all important from a practical point of view to check how the introduction of new (energy-saving and pro-ecological) technological solutions will affect the structure of operating costs, especially for residential buildings. For a resident, economic considerations are just as important as (and perhaps more important than) ecological aspects. The subject matter fits into the discussion on possible solutions applied in sustainable construction, understood as friendly to the natural environment and man, who implements the principles of sustainable development through methods of saving natural resources and prevents environmental pollution [3, 7].

In connection with the above, the aim of the article is to identify and compare the operating costs of a detached single-family residential building designed in a passive standard ("near zero-energy") using different variants of technological solutions for heating and ventilation supported by a photovoltaic system (three technological variants). Following the analysis, a technological variant using an economic criterion based on the minimization of annual operating costs was selected. The implementation of the research goal required the use of the following research methods: analysis of the literature on the subject as well as Polish and European legislation, analysis of source documentation, and calculation based on the cost calculation. 


\section{Operating Costs of Heating and Ventilation System for Selected Project}

\subsection{Technological Solutions Used in Exemplary Single-Family Residential Building}

The subject of the research is a designed single-family residential building (a model house) implemented on a housing estate in the suburban area of the city of Bydgoszcz with a usable area of $136.67 \mathrm{~m}^{2}\left(183.27 \mathrm{~m}^{2}\right.$ including a garage). It is an object with two above-ground stories, no basement, and with a terrace. It is a conventional building using masonry technology: walls made of SILKA E18 silicate blocks with EPS polystyrene insulation with a thickness of $25 \mathrm{~cm}$, reinforced concrete ceilings, and a steep roof covered with a titanium-zinc sheet with $20 \mathrm{~cm}$ of mineral wool insulation. The object is to be implemented as a standard with low energy consumption (Tab. 1).

Table 1. Heat demand of analyzed model house

\begin{tabular}{|l|c||}
\hline \multicolumn{1}{|c|}{ Parameter } & Value \\
\hline \hline Climate zone & II \\
\hline Internal temperature & $\begin{array}{c}20^{\circ} \mathrm{C} \text { in rooms intended for permanent stay of } \\
\left.\text { people (bathrooms }-24^{\circ} \mathrm{C}\right)\end{array}$ \\
\hline Height of the story & $2.6 \mathrm{~m} / 2.52 \mathrm{~m} / 2.5 \mathrm{~m}$ \\
\hline Location relative to direction & $\mathrm{N}, \mathrm{S}, \mathrm{E}, \mathrm{W}$ \\
\hline $\begin{array}{l}\text { Demand for energy of building } \\
\text { (based on energy performance } \\
\text { certificate) }\end{array}$ & $\begin{array}{c}\text { Indicator of annual demand for usable energy: } \\
\text { EU }=33.4 \mathrm{kWh} /\left(\mathrm{m}^{2} \cdot \text { year) (including cooling) }\right. \\
\text { Heat demand excluding cooling: } \\
\mathrm{EU}=28.1 \mathrm{kWh} /\left(\mathrm{m}^{2} \cdot \text { year) }\right.\end{array}$ \\
$\begin{array}{l}\text { Indicator of annual demand for primary energy: } \\
\mathrm{EP}=13.8 \mathrm{kWh} /\left(\mathrm{m}^{2} \cdot \text { year) }\right.\end{array}$ \\
\hline \hline
\end{tabular}

For the purpose of this article, three variants of various technological solutions in the field of construction of central heating and ventilation have been prepared for the near zero-energy building standard:

- VARIANT 1 (HEAT PUMP + RECUPERATOR) - heating installation using air heat pump technology. The heating was designed as a system based on air conditioning in utility rooms with support in the form of a heating mat in the bathroom. Mechanical ventilation with recuperation. An air-handling unit with heat recovery and a capacity of $270 \mathrm{~m}^{3} / \mathrm{h}$ has a programmable controller that allows for a temporary reduction in ventilation efficiency. A hydraulic module with a heating power of $9 \mathrm{~kW}$ has been designed with a built-in electric heater with a power of $4 \mathrm{~kW}$. The addition of the CWU system is a Solter 2601 heater with an electric heater with a power of $1.5 \mathrm{~kW}$. Operating parameters of the hot-water system obtained from the heat pump: $50^{\circ} \mathrm{C}$. 
- VARIANT 2 (HEAT PUMP + RECUPERATOR + PHOTOVOLTAIC) - design solutions indicated in Option 1 will be supplemented with photovoltaic panels converting solar energy into electricity. Twenty-two photovoltaic panels with a total power of $5.5 \mathrm{~kW}$ were designed on the roof of the reference house.

- VARIANT 3 (GAS + GRAVITATION VENTILATION) - central heating was designed as a radiator and floor heating system fed from a dual-function gas furnace and gravitational ventilation was proposed.

\subsection{Structure of Operating Costs of Heating and Ventilation System in Relation to Costs of Electricity in Terms of Variants}

First, the costs of electricity that could potentially be consumed in the reference house (other than the heating and ventilation system) have been determined. The demand for electricity is an estimated value, depending on the level of equipment in the electricity receivers and the number of people in residence. The electricity consumption was assumed for a single-family house inhabited by four people at $4000 \mathrm{kWh} /$ year [8]. Thus, the cost of purchasing electricity (EE) for other purposes in the model house will amount to 1,935.84 PLN/year. Next, the operating costs of the central heating and ventilation system for the three variants of the technological solutions were determined. The results are shown below.

VARIANT 1 (HEAT PUMP + RECUPERATOR). The operating costs of the central heating and ventilation system include two cost groups:

- Costs related to required inspections and maintenance, including costs of equipment servicing, de-molding of the installation, and replacement of filters carried out twice a year (before and after the heating season). The cost of the servicing carried out by a service technician authorized by the manufacturer is approx. 712 PLN/year.

- Costs related to electricity consumption - for the analyzed variant, the annual electricity consumption for the devices of the heating and ventilation system in the amount of $1,722.08 \mathrm{KWh} /$ year was balanced that, according to rates on January 1, 2018, at the electricity seller ENEA S.A. [8], gives an amount of 720.17 PLN/year.

VARIANT 2 (HEAT PUMP + RECUPERATOR + PHOTOVOLTAIC). The operating costs include the costs related to the required inspections and maintenance as well as related to the consumption of electricity, taking into account the electric energy produced in-house:

- Costs related to the technical inspection of the heat pump and recuperator were determined as in Variant 1 in the amount of 712.00 PLN/year. The mounted solar panels on the roof do not require service inspections (the manufacturer provides a 12-year warranty). The required electrical measurements in a five-year cycle are performed comprehensively with other measurements; thus, they were omitted in further calculations. 
- Costs related to the distribution and purchase of electricity. Pursuant to the law [9], a person purchasing energy on the basis of a comprehensive contract with an energy seller and producing electricity solely from renewable energy sources in micro-installations for its own consumption is called a prosumer. A prosumer with surplus electricity generated transfers it to the network in which it is stored. During the periods when the installation does not produce energy (e.g., at night), the prosumer uses the previously given energy to the network in the dimension 0.8 (for installations up to $10 \mathrm{~kW}$ ) based on the readings of the measuring and accounting device. This means that, from every $1 \mathrm{kWh}$, you can download $0.8 \mathrm{kWh}$ free of charge. From the amount of energy consumed, the prosumer does not pay fees for its settlement nor does he pay distribution fees. Importantly, the surplus of the amount of electricity introduced by the prosumer to the grid in relation to the amount of energy he collected from this network in a given settlement period is available to the seller (in order to cover the settlement costs) (Tab. 2).

The calculation of the operating costs in annual terms for Variant 2 is presented below:

- energy used for current consumption:

$5500 \mathrm{kWh} \cdot 30 \%=1650 \mathrm{kWh}$,

- energy necessary to be downloaded from the network:

$5725 \mathrm{kWh}-1650 \mathrm{kWh}=4075 \mathrm{kWh}$, of which:

- energy available for download from the grid as part of the surplus produced: $5500 \mathrm{kWh} \cdot 0.7 \cdot 0.8=3080 \mathrm{kWh}$,

- energy required to purchase from the seller: $5725 \mathrm{kWh}-(1650 \mathrm{kWh}+3080 \mathrm{kWh})=995 \mathrm{kWh}$.

Table 2. Assumptions for calculating annual costs of electricity consumption for model house - Variant 2

\begin{tabular}{||c|c||}
\hline \multicolumn{1}{|c|}{ Parameter } & Value \\
\hline \hline \multicolumn{2}{|c|}{ Annual electricity demand for analyzed model house } \\
\hline Electricity demand for heating and ventilation [kWh/year] & $1,722.08$ \\
\hline $\begin{array}{l}\text { Average demand for electricity without electric heating, instantaneous } \\
\text { water heater, with electric kitchen [kWh/year] [8] }\end{array}$ & 4000 \\
\hline Electricity demand for photovoltaic panels [kWh/year] & 2.92 \\
\hline Sum Amount of electricity produced by photovoltaic panels on annual basis \\
\hline \multicolumn{2}{|c|}{5725} \\
\hline Photovoltaic power [kWp] & 5.5 \\
\hline Produced electric energy* [kWh/year] & 5500 \\
\hline
\end{tabular}


Table 2. cont.

\begin{tabular}{|l|c|}
\hline \multicolumn{1}{|c|}{ Parameter } & Value \\
\hline \hline Own consumption [\%] & 30 \\
\hline Energy seller & Enea S.A. \\
\hline Tariff & G11 \\
\hline
\end{tabular}

* Actual production of electricity may be slightly higher or lower depending on numerous external factors such as weather conditions (high cloudiness or lack of clouds) or the occurrence of the shadowing of the modules or their fragments.

Taking into account the average electricity consumption for other purposes, the cost of purchasing electricity in the model house implemented in accordance with Variant 2 will be EE2 $=506.32$ PLN/year.

VARIANT 3 (GAS + GRAVITATION VENTILATION). The operating costs for this variant include two cost groups:

- Costs related to checking the technical condition of the installation and the boiler. In accordance with legal regulations, inspection of the gas system is required once a year [1]. The cost of servicing carried out by a service technician authorized by the manufacturer is approx. 350 PLN/year.

- Costs related to the distribution and purchase of gas: 779.78 PLN/year; and costs related to the purchase of electricity for the condensing boiler operation: 22.83 PLN/year (Tab. 3).

Table 3. Assumptions for calculation of annual costs of gas consumption and boiler operation - Variant 3

\begin{tabular}{|l|c|}
\hline \multicolumn{1}{|c|}{ Parameter } & Value \\
\hline \hline Heat demand of building $\left[\mathrm{kWh} /\left(\mathrm{m}^{2}\right.\right.$.year $\left.)\right]$ & 28.10 \\
\hline Heated area (usable area) $\left[\mathrm{m}^{2}\right]$ & 142.26 \\
\hline Heat demand of building with hot water [kWh/year] & $3,997.51$ \\
\hline Efficiency of boiler & 0.94 \\
\hline Heat demand of building including boiler efficiency [kWh/year] & $4,237.36$ \\
\hline Gas supplier & PSG Sp. z o.o. \\
\hline Gas seller & PGNiG S.A. \\
\hline Tariff & W-2.2 \\
\hline Annual cost of gas distribution and purchase for heating system & 797.78 \\
\hline $\begin{array}{l}\text { Annual cost of distribution and purchase of electricity for condensing } \\
\text { boiler }\end{array}$ & 22.83 \\
\hline
\end{tabular}


Taking into account the average electricity consumption for other purposes, the cost of purchasing electricity in the model house implemented in accordance with Variant 3 will be EE3 = 1,958.67 PLN/year.

\section{Comparative Analysis}

The operating costs of the model house are presented in three technological variants in which various design solutions for the construction of a heating and ventilation system supported by a photovoltaic system have been proposed. Depending on the variant adopted, these costs included the purchase of electricity, purchase of gas, and costs related to the service and assessment of the technical condition of the installation on a yearly basis. In addition, the analysis includes the cost of purchasing electricity for other purposes. The calculation of all cost items did not include VAT. The summary of the calculated quantities is given in Table 4, and their graphical interpretation is shown in Figure 1.

Table 4. Comparison of annual operating costs [PLN/year] of analyzed model house in variant approach

\begin{tabular}{|c|c|c|c|c|c|c|c|}
\hline \multirow[b]{2}{*}{$\begin{array}{c}\text { Technological } \\
\text { variant }\end{array}$} & \multicolumn{4}{|c|}{ Heating system and ventilation } & \multicolumn{3}{|c|}{$\begin{array}{c}\text { Heating, ventilation system, } \\
\text { and electricity }\end{array}$} \\
\hline & $\begin{array}{l}\text { cost of } \\
\text { control } \\
\text { and } \\
\text { mainte- } \\
\text { nance }\end{array}$ & $\begin{array}{l}\text { cost of } \\
\text { buying } \\
\text { electri- } \\
\text { city }\end{array}$ & $\begin{array}{l}\text { cost of } \\
\text { buying } \\
\text { gas }\end{array}$ & $\begin{array}{l}\text { cost of } \\
\text { opera- } \\
\text { tion }\end{array}$ & $\begin{array}{c}\text { cost of } \\
\text { buying } \\
\text { electri- } \\
\text { city for } \\
\text { other } \\
\text { pur- } \\
\text { poses } \\
\text { without } \\
\text { photo- } \\
\text { voltaics }\end{array}$ & $\begin{array}{l}\text { total } \\
\text { cost of } \\
\text { buying } \\
\text { electri- } \\
\text { city }\end{array}$ & $\begin{array}{l}\text { total } \\
\text { cost } \\
\text { of ope- } \\
\text { ration }\end{array}$ \\
\hline $\begin{array}{l}\text { VARIANT } 1 \\
\text { (HEAT PUMP } \\
\text { + RECUPERATOR) }\end{array}$ & 712.00 & 720.17 & - & $1,432.17$ & \multirow{3}{*}{$1,935.84$} & $2,656.01$ & $3,368.01$ \\
\hline $\begin{array}{l}\text { VARIANT } 2 \\
\text { (HEAT PUMP } \\
\text { + RECUPERATOR } \\
\text { + PHOTOVOLTAIC) }\end{array}$ & 712.00 & - & - & 712.00 & & 506.32 & $1,218.32$ \\
\hline $\begin{array}{l}\text { VARIANT } 3 \\
\text { (GAS } \\
\text { + GRAVITATION } \\
\text { VENTILATION) }\end{array}$ & 350.00 & 22.83 & 797.78 & $1,170.61$ & & $1,958.67$ & $3,106.45$ \\
\hline
\end{tabular}


Total cost of operation [PLN/year]

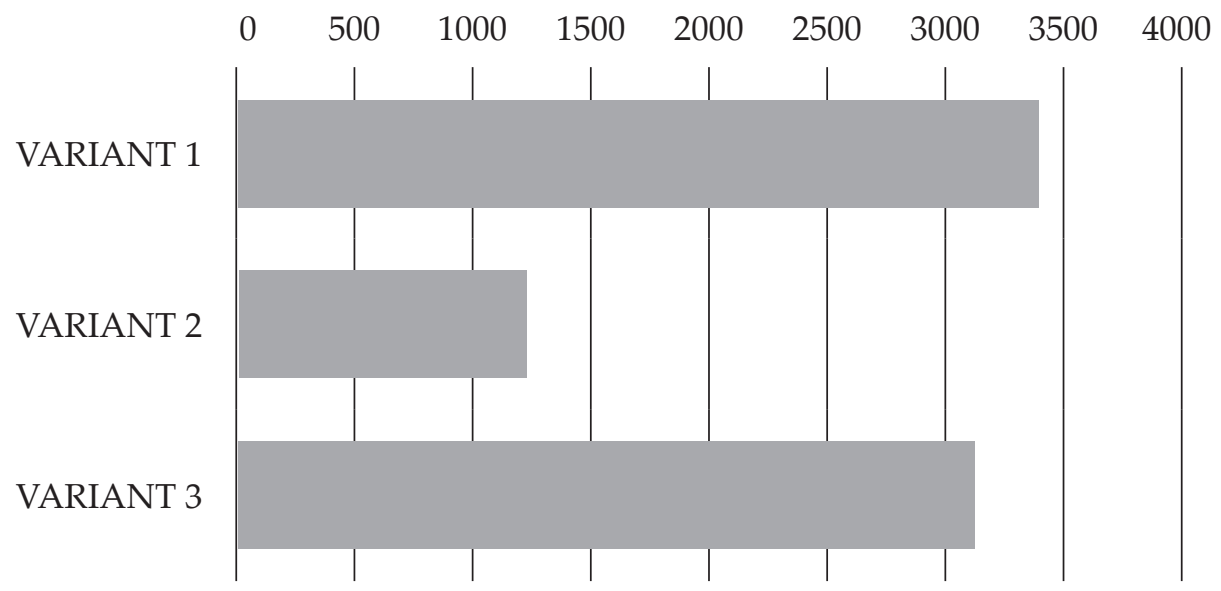

Fig. 1. Total cost of operation a model house in variants approach

\section{Conclusions}

The research carried out leads to the following final conclusions:

- The analyzed model house is characterized by a very low demand for annual computational demand for non-renewable primary energy for heating, ventilation, cooling, and domestic hot water preparation amounting to $13.8 \mathrm{kWh} /\left(\mathrm{m}^{2} \cdot\right.$ year $)$, while under the current Polish law [9], the maximum demand for this energy from January 1, 2017, to December 31, 2020, is $\mathrm{EP}=95\left[\mathrm{kWh} /\left(\mathrm{m}^{2} \cdot\right.\right.$ year $\left.)\right]$. Starting on January 1, 2021, this will be limited to $\mathrm{EP}=70\left[\mathrm{kWh} /\left(\mathrm{m}^{2} \cdot\right.\right.$ year $\left.)\right]$.

- This low energy demand translates into low building operating costs. The cheapest in service is the model house made in Variant 3 with gas heating and mechanical ventilation, amounting to 3,106.45 PLN/year. Variant 1, which proposes environmentally friendly solutions in the form of a heat pump and recuperator, generates an annual operating cost of 3,368.01 PLN/year. The difference between the variants is only $261.56 \mathrm{PLN} /$ year, which is about $8.5 \%$ more for the pro-ecological Variant 1, which eliminates the emission of harmful substances into the atmosphere.

- Lowering the cost of operating the house with a heat pump and recuperator is a technological solution presented in Variant 3, supported by a photovoltaic system (definitely the cheapest of all of the considered variants), reducing the cost of operating a model house to 1,218.32 PLN/year. 
The conducted analysis showed that using the selection criterion based on the minimization of annual operating costs (Variant 2) is the most advantageous, in which energy-saving and environmentally friendly solutions (heat pump, recuperator, and photovoltaic technology) were used in a residential building.

\section{References}

[1] Ustawa z dnia 20 lutego 2015 o odnawialnych źródłach energii. Dz.U. 2015, poz. 478, tekst jednolity: Dz.U. 2017, poz. 1148 [Journal of Laws of 2015, poz. 478, consolidated text: Journal of Laws of 2017, Item 1148].

[2] Ustawa z dnia 7 lipca 1994 Prawo budowalne. Dz.U. 1994, nr 89, poz. 414, tekst jednolity: Dz.U. 2017, poz. 1332 [Journal of Laws of 1994, No. 89, Item 414, consolidated text: Journal of Laws of 2017, Item 1332].

[3] Directive 2006/32/EC of the European Parliament and of the Council of 5 April 2006 on energy end-use efficiency and energy services and repealing Council Directive 93/76/EEC. Official Journal of the European Union, L 114/64, 27.4.2006.

[4] Directive 2012/27/EU of the European Parliament and of the Council of 25 October 2012 on energy efficiency, amending Directives 2009/125/EC and 2010/30/ EU and repealing Directives 2004/8/EC and 2006/32/EC. Official Journal of the European Union, L 315/14,11.2012.

[5] Gałązka T.: Krajowy plan mający na celu zwiększenie budynków o niskim zużyciu energii. [in:] Wesołowska M. (red. nauk.), Budownictwo energooszczędne w Polsce: stan i perspektywy, Wydawnictwa Uczelniane Uniwersytetu Techniczno-Przyrodniczego w Bydgoszczy, Bydgoszcz 2015, pp. 7-19.

[6] Napiórkowska-Baryła A., Zera M.: Ograniczanie zjawiska ubóstwa energetycznego przy pomocy termomodernizacji budynków [Reducing Fuel Poverty by Thermomodernisation of Buildings]. Acta Scientiarum Polonorum Administratio Locorum, no. 17(1), 2018, pp. 51-62.

[7] Krajowy plan działań dotyczacy efektywności energetycznej dla Polski 2017. Ministerstwo Energii, Warszawa 2017.

[8] Pawłowski K., Krause P., Sztubecka M., Topoliński S., Nakielska M., Bujarkiewicz A., Mrówczyńska M., Sztubecki J.: Budownictwo zrównoważone. Wybrane aspekty projektowe i wykonawcze. T. 1. Wydawnictwa Uczelniane Uniwersytetu Technologiczno-Przyrodniczego w Bydgoszczy, Bydgoszcz 2017.

[9] Rozporzadzenie Ministra Infrastruktury $i$ Budownictwa $z$ dnia 14 listopada 2017 r. zmieniajace rozporzadzenie w sprawie warunków technicznych, jakim powinny odpowiadać budynki i ich usytuowanie. Dz.U. 2017, poz. 2285 [Journal of Laws of 2017, Item 2285]. 


\section{Analiza porównawcza \\ kosztów ogrzewania, wentylacji i energii elektrycznej \\ na przykładzie budynku mieszkalnego \\ w standardzie niemal zeroenergetycznym}

Streszczenie: W artykule przedstawiono analizę kosztów eksploatacji budynku projektowanego w standardzie "niemal zeroenergetycznym", przy różnych wariantowych rozwiązaniach technologicznych ogrzewania i wentylacji wspomaganych systemem fotowoltaicznym (trzy warianty technologiczne). W następstwie przeprowadzonych analiz zarekomendowano wybór wariantu technologicznego przy zastosowaniu kryterium ekonomicznego opartego na minimalizacji rocznych kosztów eksploatacji.

\section{Słowa}

kluczowe: budynek o niskim zużyciu energii, koszty eksploatacji, gaz ziemny, pompa ciepła, system fotowoltaiczny 